\title{
Małgorzata Brojak-Trzaskowska
}

Uniwersytet Szczeciński

e-mail: malgorzata.brojak@wzieu.pl

\section{INNOWACJE JAKO ŹRÓDŁO KONKURENCYJNOŚCI W GOSPODARCE TURYSTYCZNEJ NA PRZYKLADZIE PRZEDSIĘBIORSTW \\ INNOVATIONS AS A SOURCE OF COMPETITIVENESS IN THE TOURISM ECONOMY ON THE EXAMPLE OF ENTERPRISES}

DOI: $10.15611 /$ pn.2017.489.05

JEL Classification: O31

Streszczenie: Przedmiot zainteresowań badawczych ujętych w pracy koncentruje się na wybranych aspektach działań innowacyjnych przedsiębiorstw turystycznych. Dobór tematyki jest implikacją rangi innowacyjności jako źródła kreacji konkurencyjności współczesnych podmiotów gospodarczych oraz znaczenia sektora turystyki dla rozwoju gospodarki w ogóle. Celem badania jest odpowiedź na pytanie, czy innowacje rzeczywiście stanowią o konkurencyjności w gospodarce, przy czym obiektem badania są przedsiębiorstwa turystyczne. Jest to konsekwencją właściwości tych podmiotów i samej turystyki, a także zbyt dużej złożoności systemu gospodarczego jako całości, uniemożliwiającą dogłębne zbadanie tej problematyki w skali makroekonomicznej. Tak sformułowany cel przeprowadzonego badania, przy uwzględnieniu zarysowanych założeń, zdeterminował układ artykułu, a także dobór metod badawczych, tj. konkretyzując analizy, zarówno w warstwie teoretycznej, jak i empirycznej, oraz syntezy, zwłaszcza w konstruowaniu wniosków z badań.

Słowa kluczowe: gospodarka turystyczna, innowacja, przedsiębiorstwo turystyczne.

Summary: The article presents selected aspects of innovation in tourism companies. Importantly, innovation is a factor of competitiveness in the modern economy. The purpose of the study is to answer the question: Do innovations really constitute the competitiveness of tourism enterprises? Critical literary studies were used in the theoretical part of the article and the analysis and synthesis methods in the empirical one. In view of the above, the main objective of the research and, consequently, of the analysis presented in the study, is to outline the specificity of innovation in tourist companies, with particular focus on the types of innovations initiated and propagated in tourism, as well as to propose matter-of-fact recommendations on how to increase innovation dynamism in the companies subjected to the analysis.

Keywords: tourism economy, innovation, tourist enterprise. 


\section{Wstęp}

W obecnych czasach innowacyjność przedsiębiorstw, tj. ich zdolność do upowszechniania innowacji, uznaje się powszechnie za czynnik decydujący o ich przetrwaniu, a przede wszystkim rozwoju. Jest istotną determinantą procesów rozwojowych i jednocześnie komponentem potencjału konkurencyjnego przedsiębiorstw. Współcześnie innowacje rozpatruje się przede wszystkim w kontekście generowania i wprowadzania nowatorskich zmian. Co istotne, nie muszą to być zmiany związane z wynalazczością, a więc odnoszące się do płaszczyzny techniczno-technologicznej, tzw. innowacje „twarde” (rzeczowe, materialne), ale mogą dotyczyć aspektów procesowych, organizacyjnych i marketingowych. Są to wówczas tzw. innowacje „miękkie” (niematerialne). Ponadto innowacje niekoniecznie muszą być zmianami radykalnymi, absolutnymi czy też nowościami przełomowymi na skalę światową lub krajową. Mogą to być również znaczące ulepszenia dotychczasowego stanu, a także rozwiązania nowe z perspektywy konkretnego sektora gospodarki, regionu, a nawet przedsiębiorstwa. Należy zaakcentować jeszcze jedną ważną kwestię, a mianowicie innowacje w konkretnym podmiocie gospodarczym nie muszą być wynikiem własnej działalności rozwojowej, badawczej, racjonalizatorskiej czy uruchomionych procesów restrukturyzacyjnych, ale mogą być również następstwem skorzystania z rozwiązań wykreowanych i wdrożonych przez innych przedsiębiorców lub instytucje, np. zakupu know-how, patentów, licencji lub po prostu benchmarkingu. Ponadto $\mathrm{w}$ praktyce biznesowej istnieje możliwość nawiązania szeroko pojmowanej współpracy innowacyjnej z innymi uczestnikami rynku, np. z:

- innymi przedsiębiorstwami, co przede wszystkim umożliwia rozłożenie kosztów i ryzyka prowadzenia działalności innowacyjnej (w tym zaprojektowania i wdrożenia inwestycji o innowacyjnym charakterze) na większą liczbę jednostek gospodarczych i jednocześnie wypracowanie efektów synergicznych z tego tytułu;

- instytucjami otoczenia biznesu, szczególnie w zakresie skorzystania ze specjalistycznych usług, np. związanych z pozyskaniem dostępu do zewnętrznego finansowania przedsięwzięć innowacyjnych, a także usług informacyjnych, promocyjnych, doradczych, czyli ogólnie rzecz ujmując - wspomagających szeroko pojmowaną przedsiębiorczość, w tym jej konkretny przejaw, czyli innowacyjność.

Uwzględniając znaczenie turystyki w rozwoju społeczno-gospodarczym, zarówno w skali makro-, mezo-, jak i mikroekonomicznej, a także dynamiczny rozwój samego sektora turystyki, rozważania badawcze odniesiono właśnie do gospodarki turystycznej, a właściwie immanentnych ogniw tej gospodarki - przedsiębiorstw turystycznych, odpowiedzialnych za kreację, praktyczną implementację i dyfuzję innowacyjnych rozwiązań.

Treści poznawcze artykułu ujęto w ramach czterech części, tj. odpowiednio:

1. Wprowadzającej, obejmującej dwa pierwsze punkty, tj. wstęp zawierający uzasadnienie podjętych badań i drugi punkt porządkujący wiedzę w zakresie stanowiącym przedmiot badania. 
2. Teoretycznej, na którą składa się trzeci punkt, poświęcony kognitywnym aspektom działalności innowacyjnej w przedsiębiorstwach.

3. Empirycznej, którą tworzy czwarty punkt pracy bazujący na wynikach ankietyzacji przedsiębiorstw turystycznych w obszarze innowacji.

4. Podsumowującej wyniki przeprowadzonych badań teoretycznych i praktycznych, zawierającej najistotniejsze wnioski, w tym - co istotne - pragmatyczne z perspektywy przedsiębiorstw turystycznych.

\section{Identyfikacja i systematyzacja podstawowych pojęć w obszarze badań}

Tematyka artykułu determinuje konieczność wyjaśnienia i usystematyzowania podstawowych kategorii pojęciowych w badanym zakresie, a mianowicie przybliżenia pojęć:

- gospodarka turystyczna,

- przedsiębiorstwa turystyczne,

- innowacja.

Konieczność ta wynika również z wielopłaszczyznowości, często niejednoznaczności definicyjnej, a więc de facto różnic interpretacyjnych w wyjaśnianiu tych terminów.

Wobec powyższego, punkt wyjścia stanowi przybliżenie pojęcia gospodarka turystyczna, którą w ujęciu ogólnym utożsamia się najczęściej ze sferą działań, urządzeń oraz środków ukierunkowanych na zaspokajanie potrzeb zgłaszanych przez uczestników ruchu turystycznego [Panasiuk (red.) 2008, s. 14] lub też ogółem wyraźnie zarysowanych czynności gospodarczych ukierunkowanych na sprawny rozwój turystyki poprzez oferowanie pojedynczych usług lub ich wiązki, służących zaspokojeniu zróżnicowanych potrzeb i oczekiwań turystów, przy czym zasadniczym atrybutem gospodarki turystycznej jest jej duża złożoność [Kornak, Rapacz (red.) 2001, s. 9; Pender, Sharpley (red.) 2008, s. 15]. Dla porównania, R. Lazarek, prowadząc szerokie rozważania w badanym zakresie, stwierdza, że gospodarka turystyczna jest pojęciem szerszym znaczeniowo od terminu ,przemysł turystyczny”, jednocześnie konstatując, że dyskusja na ten temat jest w zasadzie bezprzedmiotowa i niepotrzebna. Zdaniem przywołanego badacza, gospodarkę turystyczną należy utożsamiać ze zbiorowym pojęciem, odnoszącym się zarówno do produkcji materialnej, jak i sfery usług. Autor równolegle rozróżnia bezpośrednią (typową i uzupełniającą) oraz pośrednią (nietypową) gospodarkę turystyczną, przy czym odpowiednio typowa bezpośrednia gospodarka turystyczna obejmuje działalność gospodarczą prowadzoną wyłącznie lub niemal wyłącznie na rzecz zaspokojenia potrzeb turystów, natomiast uzupełniającą bezpośrednią gospodarkę turystyczną tworzą jednostki gospodarcze, w których wydzielona część działalności (niekoniecznie w ramach struktury organizacyjnej) dotyczy turystyki, np. przedsiębiorstwa produkcyjne w zakresie wytwarzania pamiątek, sprzętu i wyposażenia turystycznego, wydawnictwa w części dotyczącej publikowania map, 
przewodników, broszur informacyjnych i promocyjnych dla turystów, podczas gdy pośrednia gospodarka turystyczna odnosi się do funkcjonowania przedsiębiorstw produkcyjnych i usługowych, których przedmiot działalności nie dotyczy żadnych typowych usług lub produktów turystycznych, wręcz określa się ją mianem gospodarki paraturystycznej [Łazarek 2004, s. 152-158]. Powyższe wyjaśnienie badanego pojęcia i jednocześnie zastosowane rozróżnienie konkretnych podsystemów kompleksowo ujmuje gospodarkę turystyczną, stanowiąc logiczny i przemyślany pogląd w tym zakresie, na którym zresztą oparto dalsze rozważania.

Kolejnym pojęciem ekonomicznym, na które zwrócono uwagę i które w kontekście prowadzonych badań i w ogóle tematyki artykułu wymaga usystematyzowania, jest przedsiębiorstwo turystyczne.

Na kanwie ogólnej teorii przedsiębiorstwa można przyjąć, że rozpatrywana kategoria pojęciowa odnosi się do wyodrębnionej grupy ludzi, którzy wykonują czynności zaspokajające określone potrzeby turystów i którzy samodzielnie podejmują decyzje strategiczne oraz taktyczne, decydujące o skuteczności działania. Są to jednostki mające środki materialne i finansowe, a także własną strukturę wewnętrzną [Gołembski (red.) 2007, s. 300]. Zaprezentowana definicja, mimo że całościowo wyjaśnia kwestię badanego pojęcia, wymaga uzupełnienia o następujące konotacje wyjaśniające:

- interpretacja ta akcentuje organizacyjne ujęcie przedsiębiorstwa turystycznego, przy czym istotną rolę w funkcjonowaniu każdego podmiotu gospodarczego odgrywa podejmowanie decyzji nie tylko długofalowych i taktycznych, ale również operacyjnych;

- przedsiębiorstwa turystyczne w toku realizowanych czynności gospodarczych powinny uwzględniać nie tylko potrzeby uczestników ruchu turystycznego, ale również ich oczekiwania i preferencje;

- przedsiębiorstwa te powinny być nastawione nie tylko na realizację celów działania ukierunkowane na rynek - klientów i ich potrzeby, ale również (czy też z punktu widzenia przedsiębiorców - przede wszystkim) tworzenie wymiernych korzyści ekonomiczno-finansowych (zysku, a więc generowanie dodatniego wyniku finansowego $\mathrm{w}$ relatywnie krótkim czasie i powiększanie wartości przedsiębiorstwa w długiej perspektywie czasowej), a w następnej kolejności na inne cele (niższego rzędu, tzw. cele podporządkowane, np. socjalne, prestiżowe);

- atrybut samodzielności wskazany w definicji zasadniczo dotyczy przedsiębiorstwa jako jednostki gospodarczej, natomiast w odniesieniu do pracowników nie zawsze ma zastosowanie - sytuacja ta dotyczy np. pracy grupowej, w zespołach zadaniowych, projektowych lub warunków typowych dla scentralizowanego systemu zarządzania konkretnym przedsiębiorstwem.

Podsumowując tę część rozważań, stwierdzono, że przedsiębiorstwo turystyczne oznacza jednostkę gospodarczą wyodrębnioną pod względem prawnym (nie musi mieć jednak osobowości prawnej, np. przedsiębiorstwo osoby fizycznej, spółka cywilna), techniczno-organizacyjnym (dysponuje określonymi środkami trwałymi, ma własną strukturę, niekoniecznie sformalizowaną) i ekonomicznym (ma zróżnicowane zasoby, 
które stopniowo zużywają się, ale jednocześnie przenoszą wartość zużycia na usługi lub produkty turystyczne i tym samym generują wymierne korzyści ekonomiczno-finansowe dla samych usługodawców w turystyce - zysk, ale również określoną wartość dla innych grup interesu, zwłaszcza usługobiorców, czyli przede wszystkim turystów). Jest podmiotem gospodarki turystycznej, działającym w sferze produkcji materialnej i/lub usługowej, przy czym efekty tej działalności służą zaspokojeniu zróżnicowanych potrzeb turystów. Zaprezentowana interpretacja pojęcia przedsiębiorstwo turystyczne dotyczy szeroko ujmowanej działalności gospodarczej na rzecz turystów, nie tylko w zakresie organizacji i pośrednictwa turystycznego, agencji turystycznych, rekreacji, usług noclegowych, tj. reprezentujących bezpośrednią typową gospodarkę turystyczną, ale również podmiotów z bezpośredniej uzupełniającej gospodarki turystycznej, a nawet tzw. pośredniej gospodarki turystycznej.

Pojęciem wymagającym wyjaśnienia jest również innowacja, w tym postrzegana przez pryzmat sektora usługowego w ogóle czy też konkretyzując z punktu widzenia turystyki.

Innowację w turystyce z jednej strony można rozpatrywać w szerokim znaczeniu (sens largo), tj. odnosząc to zjawisko do ogólnego wymiaru społeczno-gospodarczego, a więc z punktu widzenia gospodarki jako całości (systemu gospodarczego), lub też konkretyzując z punktu widzenia gospodarki turystycznej jako podsystemu gospodarki narodowej, a nawet z punktu widzenia konkretnej formy (rodzaju) turystyki i jej specyficznych właściwości lub też konkretnego przedsiębiorstwa turystycznego (sensu stricto).

Ogólnie rzecz ujmując, innowacja wiąże się przede wszystkim z transferem wiedzy, którą następnie wykorzystuje się w nowy sposób [Hildreth, Kimble 2004, s. 81]. Zdaniem P.F. Druckera, innowacja odnosi się do systematycznego odcinania się od tego, co przestarzałe, i jednocześnie ciągłego poszukiwania okazji do wprowadzenia nowości w obszarze technologicznym, procesach, potrzebach i brakach rynkowych. Wyraża się w gotowości do organizowania się dla przedsiębiorczości i jednocześnie tworzenia nowych biznesów [Drucker 1995, s. 65-66]. W tym kontekście rozpatrywane zagadnienie wiąże się de facto z innowacyjną przedsiębiorczością, zatem szerokim pojmowaniem innowacji.

\section{Innowacja jako źródło konkurencyjności w gospodarce - aspekty teoretyczno-kognitywne}

Przedsięwzięcia innowacyjne inicjowane i realizowane w przedsiębiorstwach turystycznych mogą koncentrować się na różnych aspektach ich działalności, a mianowicie:

1. Produktach i usługach. W przypadku tego typu innowacji mamy do czynienia przede wszystkim z wprowadzaniem nowych lub w znacznym stopniu ulepszonych produktów i usług turystycznych, co w praktyce gospodarczej tych podmiotów sprowadza się do rozszerzenia dotychczasowych ofert turystycznych, np. o możliwość 
skorzystania z dodatkowych usług, np. rekreacyjnych, sportowych, kulturalno-rozrywkowych, poznawczych, czy w ogóle uprawiania nowoczesnych form turystyki. Innowacje tego typu mogą dotyczyć zarówno pojedynczych usług, jak i całych pakietów, przy czym nie muszą mieć wyłącznie pozarzeczowego charakteru, często są bowiem określoną kombinacją elementów materialnych i niematerialnych.

2. Procesach, przy czym innowacje procesowe z założenia koncentrują się przede wszystkim na nowych lub w znacznym stopniu ulepszonych metodach w zakresie świadczenia usług turystycznych, zarówno na etapie przygotowania ofert turystycznych, jak i samej obsługi turystów (poziomu i zakresu czynności składających się na ten konkretny etap procesu usługowego), tj. generalizując w odniesieniu do wszystkich działań składających się na proces świadczenia i równolegle konsumpcji usługi turystycznej.

3. Organizacji, co wymaga pewnego uzupełnienia, a mianowicie innowacje organizacyjne wyrażają się w zastosowaniu nowatorskich rozwiązań w obszarze organizacji i zarządzania przedsiębiorstwami turystycznymi - metodach, technikach $\mathrm{i}$ instrumentach.

4. Płaszczyźnie typowo marketingowej, tj. odnoszącej się do zróżnicowanych instrumentów marketingowego zarządzania przedsiębiorstwami turystycznymi, w tym wdrożenia dynamicznych i nowoczesnych metod oraz narzędzi aktywizacji sprzedaży, tworzenia nowych platform współpracy z turystami, w tym komunikacyjnych, a także stosowania nowych rozwiązań w zakresie dystrybucji usług turystycznych.

Ponadto należy zauważyć, że innowacje marketingowe mogą koncentrować się na procesie kreacji marki. Chodzi tutaj o innowacyjne działania zarówno w odniesieniu do marki regionu (miejscowości), recepcji turystycznej, jak i marki konkretnego przedsiębiorstwa turystycznego [Bednarczyk, Wszendybyl-Skulska (red.) 2013, s. 259-268].

Należy podkreślić pewne pozytywne aspekty upowszechniania innowacji we współczesnych podmiotach gospodarczych, w tym turystycznych, a mianowicie fakt, że uwzględnienie innowacji w strategii przedsiębiorstwa warunkuje jego rozwój [Szabłowski (red.) 2006, s. 103]. Ponadto innowacje determinują efektywność funkcjonowania organizacji, dlatego tak ważną rolę odgrywa zdolność do ich kreowania [Penc 2004, s. 135], a przede wszystkim systematycznego wdrażania oraz osiągania wymiernych korzyści z tego tytułu. P.F. Drucker podkreśla, że innowacje nadają dotychczasowym (dostępnym) zasobom nowe możliwości tworzenia bogactwa, jednocześnie kreując siłę nabywczą klientów, decydującą o rozwoju społeczno-gospodarczym [Drucker 1992, s. 39]. Wzmocnienie korzyści z tytułu wdrożenia innowacji zapewnia współpraca innowacyjna, niemniej punktem wyjścia jest potencjał innowacyjny samych przedsiębiorstw turystycznych [Bednarczyk, Najda-Janoszka (red.) 2014, s. 13-39]. 


\section{Innowacje w przedsiębiorstwach turystycznych - wymiar empiryczno-pragmatyczny}

Rozważania ujęte w tej części pracy koncentrują się na działalności innowacyjnej w przedsiębiorstwach turystycznych, szczególnie w obrębie korzyści generowanych przez prowadzenie działalności innowacyjnej. Refleksje te mają nie tylko poznawczy, ale również empiryczny charakter i konsekwentnie rzecz ujmując - pragmatyczny, bowiem oparto je na wynikach przeprowadzonych badań własnych (ankietyzacji), ze wskazaniem najważniejszych wniosków, istotnych z punktu widzenia przedsiębiorców świadczących usługi na rzecz uczestników ruchu turystycznego, szczególnie podmiotów reprezentujących bezpośrednią (podstawową i uzupełniającą) gospodarkę turystyczną.

Odnosząc się do przeprowadzonych badań, należy zaakcentować pewne kwestie metodyczne, a mianowicie:

1. Badanie oparto na ankietyzacji jednostek reprezentujących zbiorowość przedsiębiorstw turystycznych jako głównego podmiotu gospodarki turystycznej. Kwestionariusze pytań dostarczono respondentom przede wszystkim w tradycyjny sposób (listem poleconym) i uzupełniająco elektronicznie (drogą mailową).

2. Ankietyzację przeprowadzono w 2016 roku, objęto nią 1508 przedsiębiorstw dobranych w sposób losowy prosty ${ }^{1}$, przy czym uzyskano zwrot 254 poprawnie wypełnionych kwestionariuszy ${ }^{2}$.

3. Uzyskano materiał empiryczny, który następnie uporządkowano, zweryfikowano i przeanalizowano w zakresie stanowiącym przedmiot badania. Co istotne, uzyskane dane dotyczą szerokiego spektrum jednostek biznesowych, zróżnicowanych z uwagi na rodzaj prowadzonej działalności gospodarczej³, wielkość i formę organizacyjno-prawną przedsiębiorstw, zasięg prowadzonej działalności usługowej, a także lokalizację przedsiębiorstw turystycznych oraz sektor i formę własności badanych podmiotów gospodarczych.

\footnotetext{
${ }^{1}$ Przy takiej liczebności próby badawczej poziom istotności $(\alpha)$ ukształtował się na poziomie $2 \%$, natomiast $p$ mieści się w przedziale od 0,01 do 0,05 , co oznacza, że wyniki można uznać za statystycznie istotne.

${ }^{2}$ Formularz ankiety oparto na szerokim zestawie pytań w zakresie stanowiącym przedmiot badania, zasadniczo zamkniętych, natomiast pozostawiono respondentom możliwość wskazania własnych odpowiedzi (poza listą zaproponowanych) w ramach kategorii odpowiedzi: Inne.

${ }^{3}$ Co istotne z punktu widzenia przedmiotu prowadzonych badań, w tym złożoności samej gospodarki turystycznej, badaną zbiorowość cechuje duże zróżnicowanie pod względem sektorów i działów gospodarki narodowej w ogóle, przy czym głównie są to przedsiębiorstwa ukierunkowane na szeroko traktowane usługi, w tym noclegowe, gastronomiczne, transportu turystycznego, a także całościową obsługę potrzeb uczestników ruchu turystycznego i w relatywnie mniejszym zakresie - handlowe, które świadczą usługi nie tylko dla turystów, ale również lokalnych społeczności w miejscowościach recepcji turystycznej. Ponadto strukturę respondentów tworzą podmioty oferujące usługi przewodnickie, pilotażu turystycznego, a także organizacji wypoczynku i promocji turystycznej.
} 


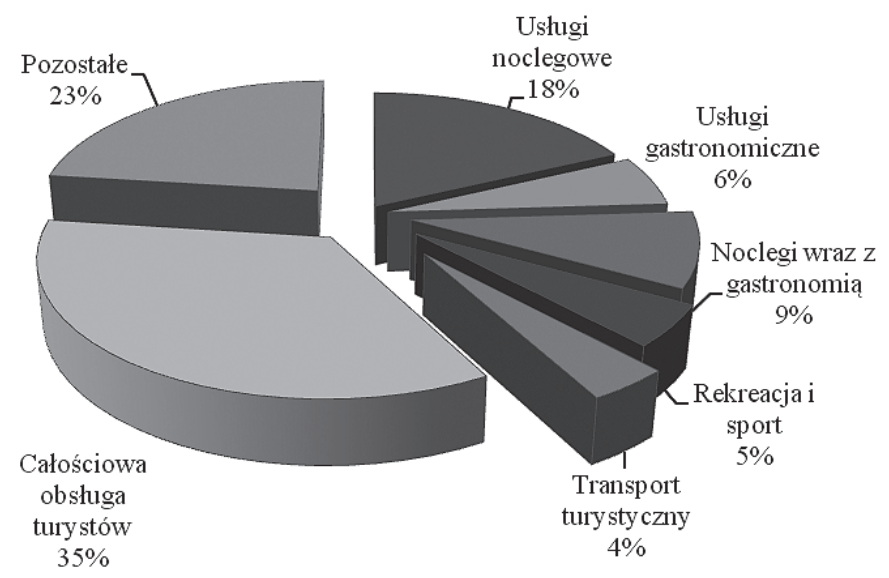

Rys. 1. Struktura respondentów według rodzaju prowadzonej działalności gospodarczej w turystyce Źródło: opracowanie własne.

Dane zaprezentowane na rys. 1 i rys. 2 wskazują, że w strukturze ankietowanych jednostek dominującą grupą są przedsiębiorstwa reprezentujące bezpośrednią typową gospodarkę turystyczną (łącznie 67\% ogółu respondentów). Pozostałe 33\% to podmioty bezpośredniej uzupełniającej gospodarki turystycznej, konkretyzując - obejmujące pozostałą działalność usługową (w tym agroturystyczną), transport i usługi gastronomiczne, a więc przedsiębiorstwa świadczące usługi nie tylko na rzecz uczestników ruchu turystycznego, ale też społeczeństwa w ogóle.

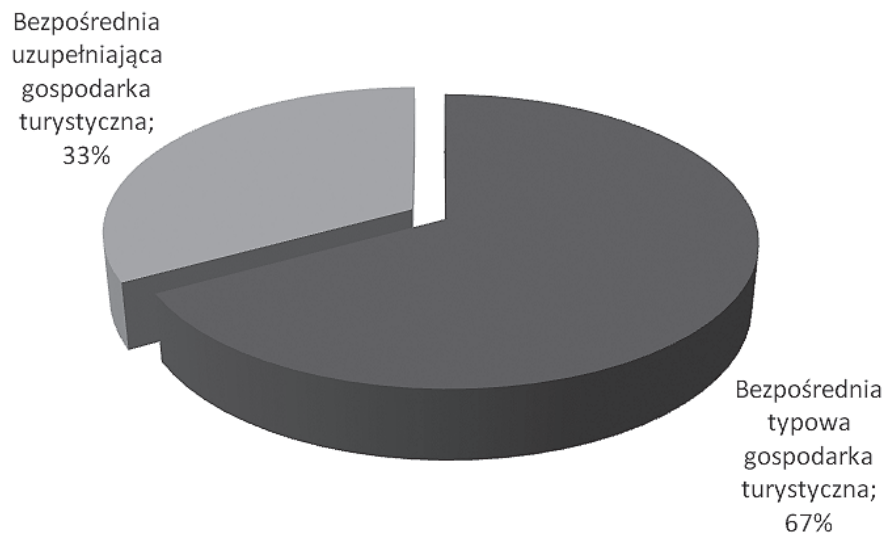

Rys. 2. Struktura respondentów ze względu na rodzaj gospodarki turystycznej

Źródło: opracowanie własne. 
Wyniki przeprowadzonych badań wskazują, że generalizując, w sektorze turystycznym mamy do czynienia z pozytywnym zjawiskiem w zakresie innowacyjności, tj. przewagą przedsiębiorstw innowacyjnych nad podmiotami, które w ogóle nie upowszechniają nowatorskich rozwiązań, tzn. nieco ponad $70 \%$ badanych wskazało, że w ciągu ostatnich lat wprowadziło przynajmniej jedną innowację, przy czym nie zawsze o charakterze oryginalnym, twórczym (czasami wręcz stosowano jedynie naśladownictwo rozwiązań wprowadzonych przez konkurencję z pewnymi elementami twórczości, czyli de facto banchmarking bazujący na tzw. innowacjach wtórnych, relatywnych i sam stanowiący przykład takiej innowacji). Konsekwencją prezentowanego szerokiego spojrzenia na innowację jest zatem tak wysoki udział innowacyjnych przedsiębiorstw turystycznych w całej badanej zbiorowości. Wyjątkiem są ci usługodawcy w turystyce, którzy reprezentują podzbiór osób fizycznych prowadzących działalność gospodarczą, najczęściej świadczących usługi gastronomiczne lub rekreacyjne. Należy dodać, że uwzględniając lokalizację respondentów według struktury administracyjnej kraju (podziału na województwa), pod względem aktywności innowacyjnej najsłabiej wypadają przedsiębiorstwa turystyczne z województwa pomorskiego, co jest wynikiem zaskakującym, jeżeli uwzględni się fakt atrakcyjności turystycznej tego konkretnego województwa w powiązaniu z wykazanym w badaniu niskim poziomem praktycznego zainteresowania przedsiębiorców w turystyce szeroko pojmowanym postępem techniczno-technologicznym i organizacyjnym. Ponadto ze względu na zasięg działania najkorzystniejszą sytuację odnotowano w przedsiębiorstwach międzynarodowych, natomiast negatywnie oceniono poziom innowacyjności podmiotów gospodarki turystycznej funkcjonujących na rynkach lokalnych.

Analizując strukturę przedsięwzięć innowacyjnych upowszechnianych przez przedsiębiorstwa turystyczne, stwierdzono, że dominujące znaczenie mają typowe innowacje usługowe, stanowiące co trzecią wdrożoną innowację, co jest następstwem specyficznych cech działalności usługowej i usług w ogóle (niematerialny charakter usługi, brak możliwości magazynowania i produkcji na zapas, jednoczesność procesu produkcji i konsumpcji itp.), zatem również sektora turystycznego. Ponadto stwierdzono, że co piąty ankietowany przedsiębiorca wprowadza innowacje procesowe i/lub marketingowe, tj. rozwiązania, które mogą być powiązane zarówno z innowacjami produktowymi, jak i usługowymi.

Rozpatrując efekty przedsięwzięć innowacyjnych inicjowanych w przedsiębiorstwach turystycznych, stwierdzono, że $\mathrm{e}^{4}$.

1. Wymiar bezpośrednio powiązany z konkurencyjnością badanych przedsiębiorstw, a w tym poprawę dotychczasowej pozycji konkurencyjnej, a także wzrost liczby klientów odnotowały 122 badane podmioty gospodarcze, co stanowi nieco ponad $18 \%$ ogółu odpowiedzi.

2. Wymiar powiązany z poprawą konkurencyjności, mający na nią wpływ, ale nie wskazany jako konkretny aspekt kształtowania konkurencyjności, w tym odpo-

\footnotetext{
${ }^{4}$ Respondenci mogli wskazać więcej niż jedną odpowiedź. Jednocześnie ośmiu przedsiębiorców nie wskazało żadnej korzyści z tytułu generowania innowacyjnych rozwiązań.
} 
wiednio na aspekty istotne z punktu widzenia usługobiorców, obejmujące zdywersyfikowanie oferty usług turystycznych adekwatnie do potrzeb klientów, poprawę jakości usług i obsługi turystów, stworzenie skuteczniejszej platformy współdziałania (np. komunikacyjnej) przypadło 168 odpowiedzi, co stanowi nieco ponad $25 \% \Sigma$ wskazań. Z kolei na płaszczyznę ekonomiczno-finansową przypadły 94 wskazania, co stanowi 14,1\% ogólnej liczby odpowiedzi respondentów na badany temat. Jednocześnie stwierdzono, że w rozpatrywanej kategorii profitów z tytułu wdrażania innowacji mamy do czynienia przede wszystkim ze wzrostem przychodów ze sprzedaży usług turystycznych i nieco mniejszym znaczeniem wzrostu zysku i poprawy rentowności prowadzonej działalności gospodarczej. Należy dodać, że wymiar ekonomiczno-finansowy jest wyraźnie sprzężony ze wzrostem konkurencyjności przedsiębiorstw turystycznych.

3. Poprawę efektywności i skuteczności działań, np. poprzez innowacje organizacyjne zapewniające wzrost wydajności pracy, a także skuteczności podejmowanych decyzji i stosowanych rozwiązań organizacyjnych, wskazało 62 respondentów ( $11 \% \Sigma$ odpowiedzi).

4. Uporządkowanie polityki rozwojowej, wzrost elastyczności działania przedsiębiorstwa turystycznego wymieniło 66 ankietowanych, co stanowi 10\% ogólnej liczby odpowiedzi.

5. Wymiar korzyści z tytułu współpracy (w tym innowacyjnej) z innymi uczestnikami rynku jako implikacja procesów innowacyjnych został wskazany przez 62 ankietowanych, co stanowi 9,2\% wszystkich odpowiedzi.

6. Wzrost społecznej odpowiedzialności biznesu jako przejaw CSR (Corporate Social Responsibility) zaakcentowało 30 przedsiębiorców świadczących usługi na rzecz uczestników ruchu turystycznego, co stanowi niemal 5\% ogółu wskazań.

7. Pomoc w szybszym i skuteczniejszym wdrożeniu innowacji jest istotna dla 26 badanych usługodawców turystycznych, co stanowi 4\% wszystkich udzielonych odpowiedzi.

8. Ułatwienia w pozyskaniu dostępu do zróżnicowanych zasobów warunkujących działalność rozwojową poprzez innowacje, szczególnie (chociaż nie wyłącznie) środków finansowych, co jednocześnie determinuje przyszły potencjał innowacyjny przedsiębiorstw turystycznych, zostały zaakcentowane przez 20 ankietowanych jednostek gospodarczych, co stanowi 3\% ogólnej liczby wskazań.

Należy zauważyć, że w zasadzie wszystkie wymienione pozytywne aspekty wdrażania innowacji bezpośrednio lub pośrednio implikują wzrost konkurencyjności przedsiębiorstw turystycznych.

\section{Zakończenie}

Uwzględniając egzemplifikację przedsiębiorstw turystycznych jako kluczowych podmiotów gospodarki turystycznej, stwierdzono, że szeroko pojmowana działalność innowacyjna generuje zróżnicowane spektrum korzyści dla samych przedsię- 
biorstw prowadzących działalność gospodarczą w turystyce, ale również innych uczestników gry rynkowej, w tym przede wszystkim turystów, społeczności lokalnych w miejscowościach recepcji turystycznej, ale także innych organizacji i przedsiębiorstw, odpowiednio:

- $\quad$ w wymiarze melioratywnym - instytucji otoczenia biznesu w zakresie usług wspomagających działalność innowacyjną i typowych przedsiębiorstw - kooperantów, np. sojuszników strategicznych w ramach aliansów strategicznych, konsorcjów i innych form współdziałania gospodarczego, a także naukowo-biznesowej współpracy innowacyjnej, co jest oczywistym zjawiskiem i co zasygnalizowano we wcześniejszych rozważaniach, tj. w aspekcie kosztów, ryzyka i efektów synergii w odniesieniu do inicjowanych i upowszechnianych przedsięwzięć rozwojowych;

- $\quad$ w wymiarze pejoratywnym - konkurentów, co wiąże się z presją konkurencyjną i potencjalnie negatywnego oddziaływania na środowisko naturalne; eliminowanie negatywnych skutków ekonomicznych, społecznych, środowiskowych, a nawet kulturowych umożliwia przestrzeganie przez przedsiębiorstwa turystyczne zasad społecznej odpowiedzialności biznesu, co zasygnalizowano we wcześniejszych rozważaniach.

Analizując pozytywne aspekty wdrażania innowacji w gospodarce turystycznej z perspektywy przedsiębiorstw turystycznych, należy podkreślić przede wszystkim znaczenie aspektów ekonomiczno-finansowych, tj. wzrostu przychodów ze sprzedaży usług turystycznych, racjonalizacji ponoszonych kosztów własnych i jednocześnie wzrostu rentowności (zwłaszcza sprzedaży) oraz spadku zadłużenia w długim horyzoncie czasu. Z kolei z perspektywy usługobiorców w turystyce podstawowe znaczenie ma poprawa jakości produktów i usług, poprawa jakości obsługi uczestników ruchu turystycznego, a także dostosowanie oferty do potrzeb klientów. Natomiast szersze spektrum korzyści uwzględnia innych interesariuszy przedsiębiorstw turystycznych, tj. kooperantów, inwestorów, lokalne społeczności w miejscowościach recepcji turystycznej, a nawet środowisko naturalne jako wyraz innowacji proekologicznych i przestrzegania zasad CSR-u.

Przeprowadzone badania pozwalają zatem jednoznacznie skonstatować, że innowacje wyrażające się w różnych płaszczyznach (usługowej, procesowej, organizacyjnej i/lub marketingowej) stanowią istotne źródło poprawy konkurencyjności przedsiębiorstw sektora turystycznego.

\section{Literatura}

Bednarczyk M., Wszendybył-Skulska E. (red.), 2013, Zarządzanie turystyka w kryzysie. Edukacja i marka, CeDeWu, Warszawa.

Bednarczyk M., Najda-Janoszka M. (red.), 2014, Innowacje w turystyce-regionalna przestrzeń wspótpracy w makroregionie południowym Polski, CeDeWu, Warszawa. 
Drucker P.F., 1992, Innowacja i przedsiębiorczość, Polskie Wydawnictwo Ekonomiczne, Warszawa.

Drucker P.F., 1995, Zarządzanie w czasach burzliwych. Nowoczesność, Akademia Ekonomiczna w Krakowie, Kraków.

Gołembski G. (red.), 2007, Przedsiębiorstwo turystyczne: ujęcie statyczne i dynamiczne, Polskie Wydawnictwo Ekonomiczne, Warszawa.

Hildreth P., Kimble C., 2004, Knowledge Networks: Innovation Trough Communities of Practice, Idea Group Publishing, London.

Kornak A.S., Rapacz A. (red.), 2001, Zarządzanie turystyka i jej podmiotami w miejscowości i regionie, Wydawnictwo Akademii Ekonomicznej we Wrocławiu, Wrocław.

Łazarek R., 2004, Ekonomika turystyki. Wybrane zagadnienia, wydanie III zmienione, Wyższa Szkoła Ekonomiczna, Warszawa.

Panasiuk A. (red.), 2008, Gospodarka turystyczna, Wydawnictwo Naukowe PWN, Warszawa.

Penc J., 2004, Narodowe i międzynarodowe systemy zarzadzania. Myślenie o jutrze w jednoczacej się Europie, Wyższa Szkoła Studiów Międzynarodowych, Łódź.

Pender L., Sharpley R. (red.), 2008, Zarządzanie turystyka, Polskie Wydawnictwo Ekonomiczne, Warszawa.

Szabłowski J. (red.), 2006, Zarządzanie innowacjami. Teoria i praktyka, Balikesir Üniversitesi, Wyższa Szkoła Finansów i Zarządzania, Białystok. 